\title{
Assessment of the impact of innovative factors on economic growth of the Russian regions
}

\author{
Svetlana N. Rastvortseva \\ Higher School of Economics, \\ Department of World Economy \\ Moscow, Russia \\ srastvortseva@gmail.com
}

\author{
Stella V. Zemlyanskaya \\ Volgograd State University, \\ Institute of Economics and Finance \\ Department of Economic Theory, \\ World and Regional Economics \\ Volgograd, Russia \\ zemlyanskayasv@volsu.ru \\ stella.zemlyanskaya@yandex.ru
}

\author{
Olga E. Akimova \\ Volgograd State Technical University \\ Faculty of Economics and Management \\ Chair of World Economics and Economic Theory \\ Volgograd, Russia \\ olafishka@mail.ru
}

\begin{abstract}
The goal of the research is the verification of the hypothesis that an innovative economic growth has a considerable importance for the regions with a high development level and is less significant in the explanation of the growth in other regions. The government and public expenditures for $R \& D$ are concentrated in a small number of the leading regions and also in those which are located closer to the industrial border. The regions beyond the borders of these technology intensive centers depend as a rule on less technological forms of innovation and on the technology transfer. We determined the following factors which are important for the regional growth: human capital, infrastructure, labour market, innovation, agglomerations interactions and productivity. As the factors characterizing the innovations we use the number of the issued patents, internal expenditures for the $R \& D$, expenditures for technological innovations, number of employees involved in the R\&D, volume of innovative goods, works and services and innovative activity of organizations. The innovations can have a positive impact on the long term growth. The data were collected in 83 regions of Russia in 2005-2015. The model of a regression with a constant elasticity was used. In the case when the impact of the competitive environment factors on the regional economic growth is significant it is difficult to assess the importance of the innovations. The division of the regions into groups according to the GDP per capita allows us showing the significant factors of their innovative growth. From the point of view of a practical application it is obvious that the regions with the development of the regions lower than average GDP per capita are expected to develop due to the innovations. Such institutional factors like management, leadership, efficient use of the potential available in the region are expected to take into account the active role of the innovations for the working force. Using as an example the Russian regions we showed that the provision of an innovative economic growth has a considerable impact for the regions with
\end{abstract}

the level of the development lower than average and is less important for the explanation of the growth in other regions.

Keywords - regional economic growth, innovative factors, technological innovations, Russian regions

\section{INTRODUCTION}

The economic growth is an integrated measure for all the activities taking place in a society [1]. The goals of the provision of the economic growth are becoming the priorities in all the countries of the world. The accelerated growth rates influence not only the welfare of the population, increase of the competitiveness of producers, create the prerequisites for the development of the social sphere but also increase the inequality level between the regions upon a number of the indices. For the provision of the economic growth the internal and external conditions for all the regions of the country are created however only the most developed from them use the advantages with the maximal efficiency. In this case the degree of the regional inequality is growing. But also an inverse trend is possible which explains faster economic growth rates by the fact that the lagging regions can adopt technological, managerial and other innovations in more developed regions and they can copy more successful practices. Such an example can lead to the convergence of regions [2].

A traditional economic policy directed on the use of such measures like a direct investment into infrastructure, subsidies and tax remissions for the attraction of new firms into the lagging regions does not give positive results in the reduction of regional discrepancies. It can be possible that for the provision of high economic growth it is important to isolate 
the main factors for some groups of regions upon the level of the social and economic development. The previous research showed that the development of the innovations and their influence on the economic growth in the regions of Russia has some specificity [3].

The goal of the researh is the verification of the hypothesis that the innovative economic growth has a considerable impact for the regions with a high development rate and is less significant in the explanation of the growth in other regions.

\section{MATERIALS AND METHODS (MODEL)}

For the development of more efficient measures a new wave of the contemporaty ideas in the sphere of the regional economic policy appeared in the European Union $[4,5]$. The scientific papers can be found which are directed on the encouragement of the growth and on the overcoming of the regional discrepancies directly by means of some measures or in parallel with the increase of the economic growth [6].

The regions of Russia vary in many measured parameters as it is easy to find some economic or cultural peculiarities and to pronounce them as the drivers of the economic growth. For the realization of a successful regional policy in the sphere of the introduction and of the use of the innovation for the promotion of the economic growth a model is necessary which would take into account the specificity of the development of some regions and also the macroeconomic factors common for all of them. Such models can help regional authorities to form an efficient combination of the projects in compliance with the available budget and the information.

There exist the results in the sphere of the construction of such models. The macro, sectoral and territorial model (MASST) was suggested by R. Capello in 2007 [7]. The geographic macro and regional model (GMR) was developed by A. Varga [8]. The model of the European Commission (RHOMOLO model) was consturcted by A. Brandsma, O. Ivanova, A. Kancs [9].

Thus, in the GMR model for Europe the following production function for knowledge is used for the region:

$$
\mathbb{A}_{i, t}^{\mathrm{X}}=R D_{i, t-k}^{\alpha_{A}} A_{N, t-k}^{\alpha_{1}}
$$

where is a temporal change (increment) of new knowledge and is assessed by the number of patents and publications in two various equations;

$\mathrm{RD}$ are the research and development and are assessed as the amount of expenditures for scientific research;

$\mathrm{A}$ is the accumulated knowledge and is measured by a total number of patents and publications correspondingly;

$\alpha_{\AA} \alpha_{\text {and }} \alpha_{2}$ are the parameters whose lower indices denote a region $(\mathrm{i})$, country $(\mathrm{N})$ and time $(\mathrm{t})$;

$\alpha_{\AA}$

is the index of the elasticity of new technological ideas in respect to the $R \& D$. It is taken as a measure of the productivity of regional research and development.
The level of the impact of the expenditures on the research and development for new technological ideas is measured by the value of the index $\alpha_{\text {A }}$. The value of this index in its turn depends on the concentration of the technologically intensive industries in the region and on the reputation of the partners of the interregional scientific and technological cooperation. In the article the conclusion is drawn that even at the equal level of the expenses for research and development the regions could generate more technological ideas concentrating in their territory technology intensive industries, attracting outstanding researches by means of the encouragement of the interregional scientific cooperation. The productivity of the research and development is a key factor of the concentration in the region of technologically intensive industries. In this way the regional policy directed on the support of the scientific research can lead to a higher level of knowledge and can lead to the growth of the circular force of the concentration of the economic activity via the growth of the productivity in the innovative sector.

In the OECD countries the empirical study was carried out for the determination of the factors of the economic growth including the innovative ones. As the experience shows the innovations have a considerable importance for the regions with a higher level of the development but they are less significant in the explanation of the growth in other regions. Both government and private expenditures for scientific research and also for the patenting activity are heavily concentrated in a small number of the regions which are located closely to a production border. The regions beyond these technology intensive centers as a rule depend on less labour intensive (more simple for measurement) forms of the innovations and the transfer of the technology what eventually explains why the innovations are not suggested as a growth factor in such regions [10].

The growth rates depend mainly on the human captial, infrastructure and innovation which are already found in the region. Such insititutional factors like administration, leadership, potential include an active role of the key actors involved into the innovations and the working force. The innovations as it seems are an important foundation for the developed regions. The innovations can be encouraged by means of serious open innovative supply chains stimulating the entrepreneurial activity and innovation clusters.

\section{RESULTS AND DISCUSSION}

When studying the innovations and their impact on the social and economic development of the regions of Russia we have attained some results $[11,12]$. The growth of innovative concentration resources is not always accompanied by the growth of the inequality between the regions upon the corresponding indices. The crisis has a negative impact on the development of the innovations in peripheral regions. Consequntly only a stable development of the economy will contribute to the distribution of the innovations in all the regions of Russia. A stable correlation between the innovative and economic development in the Russian regions appears in 2012. 
The educational level of the population is a significant factor of the economic growth and the share of the workers with higher education gives a positive impact on the economic growth rate after three years of the observation. The impact of the patent activity on the regional economic growth is a positive factor and is statistically insignificant with a two year lag.

In this research we have widened the period of the analysis beginning from 2005 in order to obtain a more representative selection even if the impact of some factors can become statistically insignificant. In order to determine whether the innovations influence the economic growth with various levels of the social and economic development we have divided 83 regions of Russia into three groups:

1) with the gross regional product (GDP) per capita higher than average in the country (I group) - 23 regions;

2) $75-100 \%$ from the average level of the gross regional product (GDP) per capita (II broup) - 20 regions;

3 ) lower than $75 \%$ from the average level of the gross regional product (GDP) per capita (III group) - 40 regions (Table 1).

Thus it is obvious that the economic growth rates are almost equal in three groups of regions. The economic growth rates vary from $1,1426 \%$ in group II to $1,1554 \%$ in group III. In group I (gross regional product (GDP) per capita higher than average in Russia) a higher share of the workers with higher education $(28,28 \%)$, a high level of employment $(66,81 \%)$, a high wage rate $(1,42$ - relation of the regional level to the average Russian index), number of patents $(791,77)$ and other factors of the innovative development are observed. A high density of the population and of the gross regional product (GDP) is also observed in the regions of this group. A high density of the roads with hard surface is found in the regions of the group III (lower than $75 \%$ from an average gross regional product (GDP) per capita across the country or 198,5 kilometer per 1000 square kilometers of territory). These regions exceed the indices of the group II according to the share of the workers with higher education and to the density of the population.

Here we suggest analyzing the influence of the factors on the regional economic growth for the period from 2005 to 2015. Taking into account that earlier the absence of a positive impact of the innovations on the economic growth was shown we will carry out a step by step analysis with the reduction of the period of the research by one year on every step of research. So the models will be constructed for the periods 2005-2015, 2006-2015 and so on till 2010-2015. By means of the use of the method of the stepwise regression we can determine the time when the effect of the innovative development becomes positive for the economic growth of the Russian regions.
TABLE I. AVERAGE VALUES OF BASIC INDICES OF THE ECONOMIC GROWTH IN THREE GROUPS OF REGIONS OF RUSSIA IN 2005-2015

\begin{tabular}{|c|c|c|c|}
\hline Index & I group & II group & III group \\
\hline & $\begin{array}{l}\text { Gross } \\
\text { regional } \\
\text { product } \\
\text { (GDP) per } \\
\text { capita higher } \\
\text { than average }\end{array}$ & $\begin{array}{l}75-100 \quad \% \\
\text { from } \quad \text { the } \\
\text { average level } \\
\text { of the gross } \\
\text { regional } \\
\text { product } \\
\text { (GDP) per } \\
\text { capita }\end{array}$ & $\begin{array}{l}\text { Lower than } 75 \\
\% \text { from an } \\
\text { average level } \\
\text { of the gross } \\
\text { regional } \\
\text { product } \\
\text { (GDP) per } \\
\text { capita }\end{array}$ \\
\hline $\begin{array}{l}\text { Gross regional product } \\
\text { (GDP) per capita, } \\
\text { thousand rubles }\end{array}$ & 504681.15 & 218851.94 & 137687.16 \\
\hline $\begin{array}{l}\text { Regional economic } \\
\text { growth, } \%\end{array}$ & 1.1552 & 1.1426 & 1.1554 \\
\hline $\begin{array}{l}\text { The density of roads } \\
\text { with hard surface, } \mathrm{km} \\
\text { per } 1000 \mathrm{~km}^{2} \text { of } \\
\text { territory }\end{array}$ & 152.5 & 169.5 & 198.5 \\
\hline
\end{tabular}

Share of the workers with higher education, $\%$

\begin{tabular}{|c|c|c|c|}
\hline 2002-2012 (3 year lag) & 25.72 & 22.67 & 23.64 \\
\hline 2003-2013 (2 year lag) & 26.53 & 23.39 & 24.37 \\
\hline 2004-2014 (1 year lag) & 27.40 & 24.14 & 25.12 \\
\hline $2005-2015$ & 28.28 & 24.91 & 25.89 \\
\hline Employment rate, $\%$ & 66.81 & 63.56 & 58.91 \\
\hline $\begin{array}{l}\text { Ratio of the average } \\
\text { wage in the region to } \\
\text { an average Russian } \\
\text { level, index }\end{array}$ & 1.42 & 0.847 & 0.68 \\
\hline Number of patents & 791.77 & 326.31 & 269.43 \\
\hline $\begin{array}{l}\text { Internal expenditures } \\
\text { for the research and } \\
\text { development, share of } \\
\text { the region, } \%\end{array}$ & 3.13 & 0.953 & 0.22 \\
\hline $\begin{array}{l}\text { Expenditures for R\&D, } \\
\text { share of the region, } \%\end{array}$ & 2.36 & 1.566 & 0.36 \\
\hline $\begin{array}{l}\text { Number of the } \\
\text { employees involved } \\
\text { into the } R \& D \text {, share of } \\
\text { the region, } \%\end{array}$ & 2.88 & 2.07 & 0.32 \\
\hline $\begin{array}{l}\text { Production of } \\
\text { innovative goods, } \\
\text { works and services, } \\
\text { mln. rubles }\end{array}$ & 49370.96 & 26738.00 & 6944.24 \\
\hline $\begin{array}{l}\text { Innovative activity of } \\
\text { the organizations, } \%\end{array}$ & 11.24 & 9.2 & 8.04 \\
\hline $\begin{array}{l}\text { Density of the } \\
\text { population, persons per } \\
\text { square kilometer of } \\
\text { territory }\end{array}$ & 524.34 & 28.71 & 33.79 \\
\hline $\begin{array}{l}\text { Density of the gross } \\
\text { regional product, } \\
\text { thousand rubles per } \\
\text { square kilometer of } \\
\text { territory }\end{array}$ & 313505.6 & 6247.6 & 4281.8 \\
\hline
\end{tabular}




\section{A. Methodology of research}

For the assessment of the innovative factors on the economic growth of the region we will use the power law model of regression with a constant elasticity.

$$
\hat{Y}_{t}=\alpha \prod_{i=1}^{m} x_{i, t-1}^{b_{i}} \text {, }
$$

where $\hat{Y}_{t}$ is the forecasted gross regional product (GDP) in the time period $t$;

$$
\begin{aligned}
& \alpha \text {-absolute term of regression; } \\
& x_{i} \text { - innovative factors included into the model of }
\end{aligned}
$$
regression;

$b_{i}$ - parameters of the equation - coefficients of regression, private coefficients of the elasticity of the gross regional product (GDP) according to the analyzed factors;

$$
\begin{aligned}
& i \text { - cardinal number of a factor; } \\
& m \text { - number of factors included into the model. }
\end{aligned}
$$

In the linear presentation the model looks in the following form:

$$
\ln \left(\frac{\hat{Y}_{i, t}}{Y_{i, t-1}}\right)=\ln \alpha+\sum_{i=1}^{m} b_{i} \ln x_{i, t-1}
$$

As a positive result we determined the growth of the index of the gross regional product (GDP) for 2005-2015. The factor indices of the model became the following ones: human capital, infrastructure, labour market, innovations, agglomeration (Figure 1).

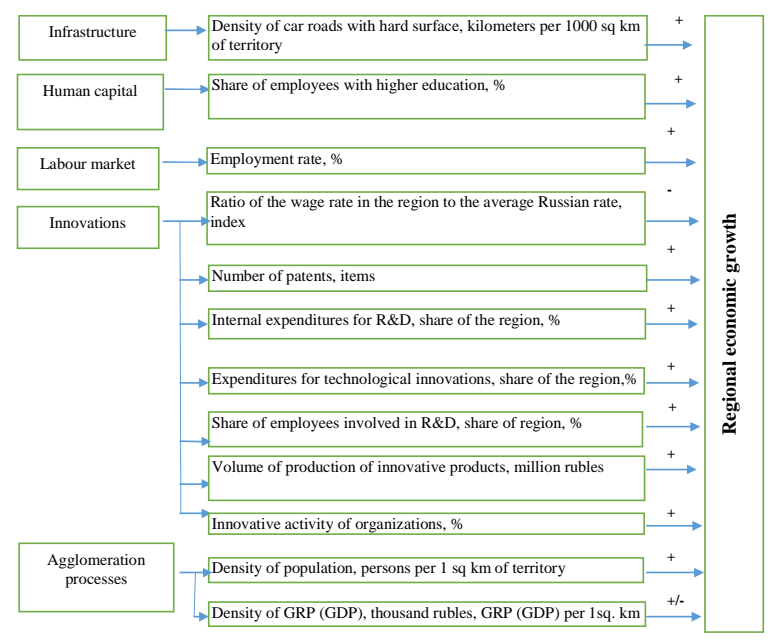

Fig. 1. Basic directions of the factor impact on the economic growth in the region.

The neoclassic theories of growth emphasize the role of the physical capital as the main factor of the economic development. We use the index of the density of the roads with hard surface (Infrast) as an indicator of the quality of the physical capital of the region [13]. The theories of the endogenous growth emphasize the human capital as the main determinant of the development. The educational level (share to the employees with higher education High_Edu, High_Edu_lag1, High_Edu_lag2 и High_Edu_lag3 for one year, two year and three year lags) is the measure of the human capital which is included into the model. The employment rate and the average wage (Wage_Ratio) give the assessment of the labour market.

The factors of the innovative development in the model include internal expenditures for $\mathrm{R} \& \mathrm{D}$, number of the patents (Patent), expenditures for technological innovations (Expend_tech_inn), number of the stuff involved into the research and development, production of innovative goods, works and services, innovative activity of enterprises. The innovations can have a positive impact on the economic growth in a long term period. The agglomeration processes are presented in the model by the density of the population (Density_pop) and the density of the gross regional product (GDP) (Density_GDP).

\section{$B$. Results of the analysis}

The results of a preliminary analysis showed that in the regions of Russia in the whole and in three groups in particular the following factors of the economic growth are statistically insignificant: employment rate; internal expenditures for $\mathrm{R} \& \mathrm{D}$; number of the workers involved in $\mathrm{R} \& \mathrm{D}$; production of innovative goods, works and services; innovative activity of organizations; density of the gross regional product (GDP). They were excluded from the model step by step. Let us

\begin{tabular}{|c|c|c|c|c|c|c|}
\hline Variable & $\begin{array}{c}2005 \\
-2015\end{array}$ & $\begin{array}{l}2006- \\
2015\end{array}$ & $\begin{array}{l}2007- \\
2015\end{array}$ & $\begin{array}{l}\text { 2008- } \\
2015\end{array}$ & $\begin{array}{c}2009 \\
-2015\end{array}$ & $\begin{array}{c}2010- \\
2015\end{array}$ \\
\hline Constant & 0,487 **** & $0,69^{* * * *}$ & $0,55^{* * * *}$ & $0,17^{* * *}$ & & $0,43^{* * * *}$ \\
\hline Infrast & $-0,018^{* * *}$ & $-0,016^{* * *}$ & $-0,016^{* * *}$ & $-0,015^{* * *}$ & $-0,015^{* * *}$ & $-0,015^{* * *}$ \\
\hline $\begin{array}{l}\text { High_Edu_ } \\
\text { lag2 }\end{array}$ & $-0,094 * * *$ & $-0,069^{* * *}$ & $-0,060^{* *}$ & & & \\
\hline $\begin{array}{l}\text { High_Edu_ } \\
\text { lag1 }\end{array}$ & & & & & $0,025^{*}$ & \\
\hline$\overline{H i g h \_E d u}$ & & & & & & $-0,044 * *$ \\
\hline$\overline{\text { Wage_Ratio }}$ & & $0,0355^{*}$ & & $-0,06^{* *}$ & $-0,092 * * *$ & \\
\hline$\overline{\text { Patent }}$ & $-0,0082^{* * * *}$ & $-0,0091 * *$ & $-0,011^{* * *}$ & $-0,01 * *$ & $-0,014 * *$ & \\
\hline$\overline{\text { Expend_R_D }}$ & & $0,006^{*}$ & $0,0068^{* * *}$ & 0,007 ** & $0,0089^{*}$ & \\
\hline $\begin{array}{l}\text { Expend_tech_ } \\
\text { inn }\end{array}$ & & & & & & $0,0035^{*}$ \\
\hline $\begin{array}{l}\text { Density_ } \\
\text { pop }\end{array}$ & $0,024 * * *$ & $0,061 * * *$ & $0,039 * * *$ & & $-0,021^{*}$ & $0,028 * * *$ \\
\hline $\begin{array}{l}\text { Density } \\
\text { GDP }\end{array}$ & & $-0,042 * * *$ & $-0,021^{* *}$ & $0,011 * * *$ & $0,03 * *$ & $-0,018^{* * * *}$ \\
\hline $\bar{N}$ & 870 & 792 & 715 & 638 & 561 & 489 \\
\hline$R^{2}$ & 0,07 & 0,125 & 0,07 & 0,025 & 0,64 & 0,069 \\
\hline$\overline{A d j R^{2}}$ & 0,062 & 0,117 & 0,062 & 0,017 & 0,64 & 0,059 \\
\hline $\bar{F}$ & $2,5 \cdot 10^{-12}$ & $1,15 \cdot 10^{-19}$ & $2,22 \cdot 10^{-9} 9$ & 0,007 & $1,5 \cdot 10^{-118}$ & $1,98 \cdot 10^{-6}$ \\
\hline
\end{tabular}
construct the models with the remaining factors of the economic growth (Table II).

TABLE II. RESULTS OF MODELING OF THE IMPACT OF INNOVATIVE FACTORS ON THE ECONOMIC GROWTH IN THE REGIONS OF RUSSIA, PANEL DATA IN ALL THE REGIONS, 2005-2015. 
The results of the empirical analysis for the whole period (2005-2015) show that the most important factors for the economic growth of Russia are the infrastructure (density of the roads with hard surface), share of the workers with higher education, number of patents and the density of the population. We include into the model the average wage of the employees and the expenditures for the technological innovations as they are important for some groups of regions. Let us construct the models of the economic growth for group I of Russian regions (with the level of the gross regional product (GDP) per capita higher than average in Russia) (Table 3).

TABLE III. RESULTS OF THE MODELING OF THE IMPACT OF INNOVATIVE FACTORS ON THE ECONOMIC GROWTH IN THE REGIONS OF THE GROUP I (WITH THE LEVEL OF THE GROSS REGIONAL PRODUCT (GDP) HIGHER THAN AVERAGE), PANEL DATA, 2005-2015

\begin{tabular}{lccc}
\hline \multicolumn{1}{c}{ Variable } & $\mathbf{2 0 0 5 - 2 0 1 5}$ & $\mathbf{2 0 0 6 - 2 0 1 5}$ & $\mathbf{2 0 0 7 - 2 0 1 5}$ \\
\hline Constant & $0,493^{* * *}$ & & $0,369^{* * *}$ \\
\hline Infrast & $-0,01^{* * *}$ & $-0,011^{* * *}$ & $-0,010^{* * *}$ \\
\hline High_Edu_lag2 & $-0,11^{* * * *}$ & & $0,087^{*}$ \\
\hline High_Edu_lagl & & $-0,135^{* * * *}$ & \\
\hline Emp_Rate & & $0,141^{* * *}$ & \\
\hline $\begin{array}{l}\text { Density_ } \\
\text { pop }\end{array}$ & $0,011^{* * *}$ & $0,011^{* * *}$ & $0,031^{* *}$ \\
\hline$N$ & 243 & 222 & 201 \\
\hline$R^{2}$ & 0,06 & 0,664 & 0,035 \\
\hline Adj $R^{2}$ & 0,04 & 0,66 & 0,021 \\
\hline$F$ & 0,027 & $1,68^{*} 10^{-50}$ & 0,068 \\
\hline
\end{tabular}

*** significance at $1 \% ; *$ s significance at $5 \%$; significance at $10 \%$. Such factors like the share of the employees with higher education with three year lag (High_Edu_lag3), wage rate (Wage_Ratio), number of patents (Patent), internal expenditures on R\&D (Expend_R_D), expenditures on technological inovations (Expend_tech_inn), number of the staff involved into the R\&D (Number_staff_R_D), production or innovative goods, works and services (Vol_inn_goods), innovative (Densi CDP) were (Density_GDP) were not included ino the model due to their low statistical significance. They are not
shown in the

The results of the empirical analysis speak about the fact that in 2005-2015 the most important factors of the economic growth in the group I of the regions of Russia are the infrastructure (density of roads with hard surface), the share of the employees with higher education and density of population. Let us construct the models for the economic growth for the group II of the regions of Russia (with the level $75-100 \%$ from an average gross regional product (GDP) per capita).

The results of the empirical analysis speak about the situation that in 2005-2015 the most important factors of the economic growth in group II became the infrastructure (density of the roads with hard surface), number of the employees with higher education, number of patents and the density of the population. The leading innovative factors of the economic growth in group II became the share of the employees with higher education and number of patents. Let us construct the models of the economic growth for group III of Russian regions (gross regional product (GDP) per capita is lower than $75 \%$ from an average level in Russia) (Table 5).

The coefficient of the determination in the constructed model will be low due to the reason that into the model mainly the innovative factors of development are included and traditional ones (labour and capital) are not taken into consideration. We would like also to mention that the growth rates of the gross regional product (GDP) in many aspects depend on the factors of the economic environment: dynamics of prices for oil, gas, non ferrous and ferrous metals (significant for the Russian economy), foreign policy, national currency exchange rate. The factors of the economic environment very often do not give the opportunity of assessing adequately the impact of the innovative factors of the economic growth.

TABLE IV. RESULTS OF THE MODELING OF THE IMPACT OF INNOVATIVE FACTORS ON THE ECONOMIC GROWTH IN THE REGIONS OF THE GROUP II (WITH THE LEVEL OF THE GROSS REGIONAL PRODUCT (GDP) PER CAPITA 75-100\% FROM AVERAGE), PANEL DATA, 2005-2015.

\begin{tabular}{|c|c|c|c|c|c|c|}
\hline Variable & $2005-2015$ & $\begin{array}{l}2006- \\
2015\end{array}$ & $\begin{array}{l}2007- \\
2015\end{array}$ & $\begin{array}{l}2008- \\
2015\end{array}$ & $\begin{array}{l}2009- \\
2015\end{array}$ & $\begin{array}{l}2010- \\
2015\end{array}$ \\
\hline$\overline{\text { Constant }}$ & $0,52 * * *$ & $0,87^{* * * *}$ & $0,746 * * *$ & 0,432 & & 0,887 *** \\
\hline Infrast & $-0,054 * * *$ & $-0,085^{* * * *}$ & $-0,087 * * *$ & $-0,117 * *$ & $-0,125^{* * *}$ & $-0,1 * * *$ \\
\hline $\begin{array}{l}\text { High_Edu_ } \\
\text { lag2 }\end{array}$ & $-0,061 * * *$ & $-0,143 * * *$ & $-0,111 *$ & $-0,163 * *$ & $-0,160 * *$ & \\
\hline$\overline{H i g h \_E d u}$ & & & & & & $-0,154 * * *$ \\
\hline$\overline{\text { Patent }}$ & $-0,018 * * *$ & $-0,043$ **** & $-0,048 * * *$ & $-0,056 * *$ & $-0,056^{* * * *}$ & $-0,032 * *$ \\
\hline Expend_R_D & & $0,024 * * *$ & $0,025 * * *$ & $0,028 * * *$ & $0,028 * *$ & $0,015^{* *}$ \\
\hline $\begin{array}{l}\text { Expend_tech_ } \\
\text { inn }\end{array}$ & & $-0,021 * * *$ & $-0,023 * * *$ & $-0,026^{* * * *}$ & $-0,0198 * * *$ & $-0,019 * *$ \\
\hline $\begin{array}{l}\text { Vol_inn_ } \\
\text { goods }\end{array}$ & & $0,0158 * *$ & $0,021 * * *$ & $0,021 * *$ & $0,0152 * *$ & 0,0149 ** \\
\hline $\begin{array}{l}\text { Density_ } \\
\text { pop }\end{array}$ & $0,053 * * *$ & $0,082 * * *$ & $0,079 * * *$ & & $-0,088^{*}$ & $0,088^{* * * *}$ \\
\hline $\begin{array}{l}\text { Density } \\
\text { GDP }\end{array}$ & & & & $0,108 * *$ & $0,200 * * *$ & \\
\hline $\bar{N}$ & 220 & 200 & 180 & 160 & 140 & 120 \\
\hline$\overline{R^{2}}$ & 0,058 & 0,12 & 0,11 & 0,12 & 0,597 & 0,211 \\
\hline $\operatorname{Adj} R^{2}$ & 0,04 & 0,09 & 0,075 & 0,08 & 0,576 & 0,162 \\
\hline $\bar{F}$ & 0,011 & 0,0007 & 0,0045 & 0,005 & $1,03 * 10^{-22}$ & 0,0003 \\
\hline
\end{tabular}

$* * *$ significance at $1 \% ; * *$ significance at $5 \% ; *$ significance at $10 \%$. Such factors like the share of the employees with higher education with three year lag (High_Edu_lag3), employment rate (Emp_Rate), wage rate (Wage_Ratio), number of the staff involved into the R\&D (Number_staff_R_D), activity of the organizations in the region (Inn_activ) were not included into the model due to their low statistical significance. They are not shown in the table.

TABLE V. RESULTS OF THE MODELING OF THE IMPACT OF INNOVATIVE FACTORS ON THE ECONOMIC GROWTH IN THE REGIONS OF THE GROUP III (LOWER THAN $75 \%$ FROM THE AVERAGE GROSS REGIONAL PRODUCT (GDP) PER CAPITA), PANEL DATA, 2005-2015

\begin{tabular}{lcccccc}
\hline Variable & $\mathbf{2 0 0 5 - 2 0 1 5}$ & $\mathbf{2 0 0 6 -}$ & $\mathbf{2 0 0 7 -}$ & $\mathbf{2 0 0 8}-$ & $\mathbf{2 0 0 9 -}$ & $\mathbf{2 0 1 0 -}$ \\
& & $\mathbf{2 0 1 5}$ & $\mathbf{2 0 1 5}$ & $\mathbf{2 0 1 5}$ & $\mathbf{2 0 1 5}$ & $\mathbf{2 0 1 5}$ \\
\hline Constant & $0,496^{* * *}$ & $0,767^{* * *}$ & $0,602^{* * *}$ & $0,292^{* *}$ & & $0,48^{* * *}$ \\
\hline Infrast & $-0,057^{* * *}$ & & $-0,046^{* * *}$ & $-0,048^{* * *}$ & $-0,045^{* * *}$ & $-0,052^{* * *}$ \\
\hline High_Edu_ & $-0,079^{* * *}$ & & & & &
\end{tabular}

lag2

High_Edu_

lagl

\begin{tabular}{llllll}
\hline$H i g h \_E d u$ & $-0,055^{* *}$ & $-0,077^{* *}$ & $-0,06^{*}$ & $-0,18^{* * *}$ & $-0,059^{* * * *}$ \\
\hline
\end{tabular}

\begin{tabular}{llllll}
\hline Wage_Ratio & $-0,11^{* * *} \quad 0,155^{* * * *}$ & $-0,195^{* * *}$ & $-0,189 * * *$ & $-0,116^{* * *}$
\end{tabular}

\begin{tabular}{llllll}
\hline Patent & $-0,0091^{* * *}$ & $-0,0083^{* *}-0,015^{* * *}$ & $-0,014 * * *$ & $-0,014 * * *$ & $-0,008 * *$
\end{tabular}

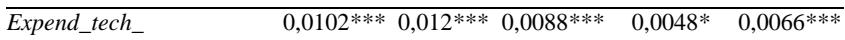

inn

Inn_activ $-0,011^{*}$

\begin{tabular}{llllll}
\hline Density_ & $0,056^{* * *}$ & $0,083^{* * *}$ & $0,039^{* * *}$ & $-0,023^{*}$ & $0,045^{* * * *}$ \\
\hline Dop & & & & & \\
\hline
\end{tabular}

\begin{tabular}{llll} 
pop & & & \\
\hline Density_ & $-0,075^{* * *}$ & $0,038^{* * *}$ & $0,068^{* * * *}$
\end{tabular}

\begin{tabular}{lllllll}
\hline$N$ & 427 & 374 & 339 & 303 & 267 & 230
\end{tabular}

\begin{tabular}{lllllll}
\hline$R^{2}$ & 0,14 & 0,23 & 0,17 & 0,11 & 0,75 & 0,19
\end{tabular}

\begin{tabular}{lllllll}
\hline Adj $R^{2}$ & 0,13 & 0,22 & 0,15 & 0,09 & 0,75 & 0,17
\end{tabular}

\begin{tabular}{lllllll}
\hline$F$ & $1,3 \cdot 10^{-12}$ & $1,74 \cdot 10^{-19}$ & $5,59 \cdot 10^{-11}$ & $5,34 \cdot 10^{-6}$ & $3,34 \cdot 10^{-74}$ & $9,57 \cdot 10^{-9}$
\end{tabular}

*** significance at $1 \%$; ** significance at $5 \%$; significance at $10 \%$. Such factors like the share of the employees with higher education with three year lag (High_Edu_lag3), employment rate Emp_Rate), number of the staff involved into the R\&D (Number_staff_R_D), production of innovative soods, works and services (Vol_inn_goods) were not included into the model due to their low statistical 
It is worth studying the model more thoroughly. For 83 regions of Russia the model which included the most significant factors has the following form:

$\frac{G D P_{t}}{G D P_{t-1}}=0.478 \cdot$ Infrast ${ }^{-0.018} \cdot H_{i g h} E d u_{-}$lag $_{2}^{-0.094} \cdot$ Patent $^{-0.082} \cdot$ Density $_{-}$pop $^{0.024}$

It is obvious that the density of the population has a positive impact on the economic growth (in all the models constructed for three groups). These data confirms the statements of new economic geography about the arising agglomerations effects from territorial population concentration. The theories of new economic geography speak about the fact that the agglomeration effects are accompanied by the spread of knowledge contributing to an innovative development. The share of the employed in the economy with higher education and the number of patents has a negative impact (but is statistically significant). For the moment in Russia the measures increasing the attractivenes of the secondary vocational education are being taken as the professionals of this type are popular in the labour market and a low supply leads to inefficiently high salaries.

In the group III (the least developed regions) the factor of the wage has a considerable impact on the economic growth. A negative impact of the number of patents confirms our conclusions or suppositions about an insufficient level of the development of this sector of the economy. It is obvous that the biggest number of patents is found in group I of the Russian regions (in average 791,77 of the patents per a region in 2005-2015). But in this group of regions the impact of the mentioned factor is not statistically significant. The model constructed for the group I of the regions has the form:

$$
\frac{G D P_{t}}{G D P_{t-1}}=0.493 \cdot \text { Infrast }^{-0.01} \cdot \text { High }_{-} \text {Edu_lag }{ }_{2}^{-0.11} \cdot \text { Density } \text { pop }^{0.011}
$$

It is worth mentioning that at the inclusion of six factors of the economic growth a significant correlation is observed in connection with the expenditures on technological innovations. The economic growth in the group of the regions with an intermediate level of development is achieved due to such innovative factors like higher education and number of patents. The influence of both of the factors is negative. The model has the following form:

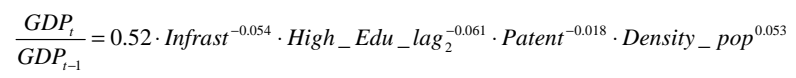

The group of the least developed regions (below $75 \%$ of average gross regional product or GDP per capita) includes 40 regions of Russia. The following factors: higher eduction, number of patents, wage rate have statistical significance for the economic growth in this group of regions. The model has the following form:

$$
\begin{aligned}
& \frac{G D P_{t}}{G D P_{t-1}}=0.496 \cdot \text { Infrast }^{-0.057} \cdot \text { High_Edu_lag }_{2}^{-0.079} \cdot \text { Wage_ratio }^{-0.11} \times \\
& \times \text { Patent }^{-0.0091} \cdot \text { Density_pop }^{0.056}
\end{aligned}
$$

It is logical to draw the conclusion about the fact that a high wage has a negative impact on the economic growth rates. A negative impact of the density of the roads with hard surface on the economic growth can be explained by considerable geographic territories of the Russian regions. The car roads are an important but not the most significant type of the transport infrastructure. In the richest regions (group I) the air, sea transport and pipelines have a considerable importance. We believe that this direction can be studied independently.

A negative impact of innovative factors on the economic growth can be explained by the following regions:

1) We analyze as a resulting index not the social and economic development of a region for a specific moment of time but we take into consideration the economic growth rates. This corresponds to the aim of our research but does not exclude a significant impact of the economic environment. The regions grow faster not due to the accumulated innovations for many years but due to a favourable external economic environment.

2) The innovations at the current stage of the development of the Russian economy are not popular in the regions for the provision of their economic growth. Their productivity is low and there are alternative ways for a quick profit making. We mentioned above that the impact of the innovations on the development of the economy of the Russian regions becomes statistically significant since 2012. We suppose that later when more data appears for a representative sample the period from 2012 can be analyzed independently.

3) The imperfetness of the data of the official statistics upon the innovations indices exists. If we take into account the share of the employed with higher education it reflects the real situation but as for such data like internal expenditures on technological innovations and $R \& D$ it is difficult to speak about their reliability what makes the analysis more complicated.

\section{CONCLUSION}

Thus the hypothesis about the situation when the regions with higher economic growth to a greater extent depend on the innovations has not been proved. In these regions the impact of the economic environment is a considerable one. In the regions with an intermediate level of development and lower the relation between the average growth rate and the innovations remains strong. The density of the population has a positive influence on the growth in all Russians regions everywhere. The results mentioned above confirm the conclusions of the new economic geography and imply the growth of agglomeration effects from the geographic concentration of the population and the knowledge what will contribute to the development of innovations.

A negative impact of the density of the car roads with hard surface can be explained by vast geographic areas of the Russian regions. The car transport is not the leading type of transportation in all the regions of Russia. A negative but a statistically significant impact of the share of the employees with higher education proves considerable imbalances in the labour market. The number of patents has an impact on the economic growth in groups II and III. In the regions of group III the wage rate has a negative impact on the economic growth. 


\section{Acknowledgment}

This paper was supported by the grant of the President of the Russian Federation, project No. NSh-3175.2018.6

\section{References}

[1] Lucas R.E. Lectures on Economic Growth. Moscow: Publishing house of Gaidar's Institute, 2013.

[2] Barro R. J., Martin X. S. I. Economic growth. Moscow: Binom Publ., 2004.

[3] Rastvortseva S. Innovation as a factor of regional economic growth: evidence from Russia. Innovation Management and Corporate Sustainability (IMACS 2015), pp. 251-262.

[4] Varga A. Place-based, spatially blind, or both? Challenges in estimating the impacts of modern development policies: the case of the GMR policy impact modeling approach. International Regional Science Review, vol. 40(1), 2017, pp. 12-37.

[5] Dvouletý O. Determinants of Nordic entrepreneurship. Journal of Small Business and Enterprise Development, vol. 24(1), 2017, pp. 12-33.

[6] World Bank. World development report 2009: Reshaping economic geography [ONLINE] Available at: http://documents.worldbank.org/curated/en/730971468139804495/pdf/4
37380REVISED01BLIC1097808213760720.pdf. [Accessed March, 21 2016].

[7] Capello R. A forecasting territorial model of regional growth: the MASST model. The Annals of Regional Science, vol. 41(4), 2007, pp. 753-787.

[8] Varga A. GMR-Hungary: A complex macro-regional model for the analysis of development policy impacts on the Hungarian economy. Department of Economics and Regional Studies. Faculty of Business and Economics. University of Pécs, 2007.

[9] Brandsma A., Ivanova O., Kancs A. Evaluation of Cohesion Policy Options with a Regional Computable General Equilibrium Model for the European Union. Regional Studies (forthcoming), 2015.

[10] Promoting growth in all regions. OECD Publishing, Paris. DOI: http://dx.doi.org/10.1787/9789264174634-en, 2012.

[11] Rastvortseva S. Innovation as a factor of regional economic growth: evidence from Russia. Innovation Management and Corporate Sustainability (IMACS 2015), pp. 251-262.

[12] Rastvortseva S. Impact of the innovations on regional growth over time: dynamic econometric modeling. Innovation Management, Entrepreneurship and Corporate Sustainability (IMECS 2016), pp. 621633.

[13] OECD. How regions grow: Trends and analysis. [ONLINE] Available at: $\quad$ http://www.oecd.org/gov/regional-policy /howregionsgrowtrendsandanalysis.htm [Accessed 24 April 09]. 